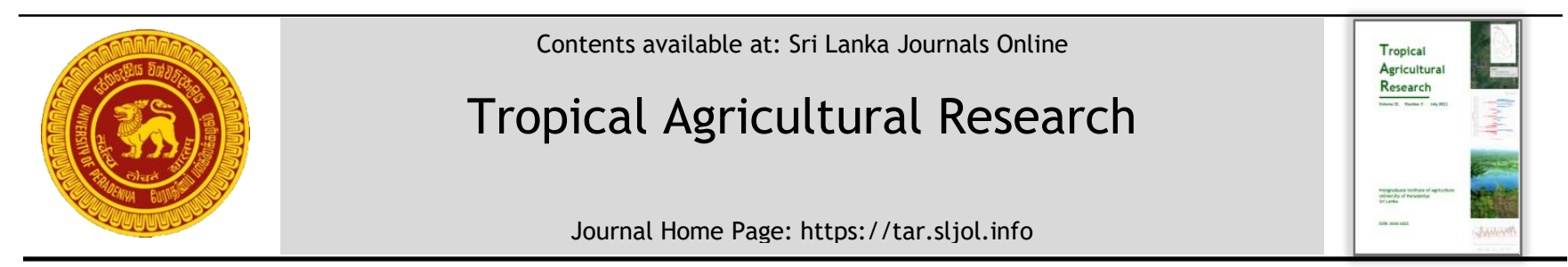

\title{
Overcoming Challenges and Achieving Sustainability of Potato Production through A Real-time Digital Knowledge-based System
}

\author{
M.S.A. Mohamed ${ }^{1,2^{*}}$, D.L. Wathugala ${ }^{1}$, W.A. Indika ${ }^{2}$ and M.K.S. Madushika ${ }^{2}$ \\ 11 Department of Crop Science, Faculty of Agriculture, University of Ruhuna, Kamburupitiya, Sri Lanka \\ ${ }^{2}$ Department of Computer Science, Faculty of Science, University of Ruhuna, Matara, Sri Lanka
}

\section{ARTICLE INFO}

\section{Article history:}

Received: 14 August 2020

Revised version received: 6 December 2020

Accepted: 19 January 2021

Available online: 30 July 2021

\section{Keywords:}

Context-specific actionable information Mobile application

Model for Packages of Practice

Overcoming challenges

Sustainable Potato production

\section{Citation:}

Mohamed, M.S.A., Wathugala, D.L., Indika, W.A. and Madushika, M.K.S. (2021). Overcoming challenges and achieving sustainability of potato production through a real-time digital knowledgebased System. Tropical Agricultural Research, 32(3): 307-317.

DOI: http://doi.org/10.4038/tar.v32i3.8494

Mohamed, M.S.A.

https://orcid.org/0000-0002-7237-0727

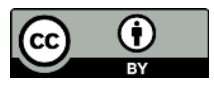

\section{ABSTRACT}

Potato is the most popular root crop and plays a crucial role in human nutrition worldwide. However, farmers in Sri Lanka face many challenges throughout at different stages of potato production. This study intends to provide context-specific actionable information using the Packages of Practice (PoP) model through an ICT-based mobile platform. To investigate farmers' challenges, a field survey was conducted in major potato growing Districts in Sri Lanka. Primary data were obtained using a pre-tested structured questionnaire, formal and informal discussions from 100 potato farmers selected by purposive sampling technique. Low farmgate prices (37\%), pest and disease attacks (32\%) and high cost of farm inputs (20\%) were the major challenges identified in the study area. These challenges were mainly due to the non-adoption of proper agronomic practices, lack of complete information at the right time, scarcity and low-quality agro-technology, etc. Further, identified decision support factors required for each stage in the farming life cycle for better cultivation. The PoP model was designed concerning the farmer context using Design Science Research methodology. Then the designed PoP was verified and validated by the experts in the domain. The ontological crop knowledge base was used to represent the PoP. Finally, knowledge in the PoP model is fed through a mobile application and then according to user requests, information is acquired from the knowledge base. The designed PoP will be modified based on the updated information/knowledge and user satisfaction/feedback. The proposed information flow will be continued cyclically. A mobile-based information system was taken as an effective tool to speed up the process of knowledge sharing among farmers by providing real-time information, promised to overcome common challenges faced by the potato farmers and achieve long-term sustainability in production.

\footnotetext{
* Corresponding author: msakeelm21@gmail.com
} 


\section{INTRODUCTION}

Potato (Solanum tuberosum L.) is a substantial upland annual crop in Sri Lanka and ranks fourth most important food crop after cereal crops such as maize, rice, and wheat (Abhayapala et al., 2014; Ghebreslassie et al., 2014). It is the number one non-grain food commodity and has grown in more than 100 countries in the world, mainly in Asia and Europe (Rykaczewska, 2013). Currently, it is cultivated in the highlands of Nuwara Eliya and Badulla, Puttalam (Kalpitiya), and Jaffna districts in Sri Lanka (Abhayapala et al., 2014; Eeswaran et al., 2016). The extent of its cultivation is about 3,300 ha and the estimated annual production is around 53,000 MT in Sri Lanka (Department of Census and Statistics - DCS, 2017). The central hills of Sri Lanka play a vital role in the economy of potato production (Bandara and Thiruchelvam, 2008). According to Food and Agriculture Organization (2009) it is known among the highly recommended food security crop that can safeguard low-income countries from the risks posed by rising international food prices.

The crop plays an important role in human nutrition worldwide which needs much less land, grows fast and without any difficulties even in rough environmental conditions (Ghebreslassie et al., 2014; Qadri et al., 2015). But the potato crop yield is mainly decided by its specific genetic background (Evans and Fischer, 1999). The conventional production systems of potatoes, never met the potential yield due to the influence of biotic and abiotic factors. Negatively interfering with these factors affect plant growth and tuber development (Michel et al., 2015). Thus, potato farmers in Sri Lanka face many challenges mainly as poor yield due to pest and disease attacks, improper soil fertility management, extreme use of synthetic chemicals and unbalanced use of inorganic fertilizers, and non-availability of good quality seed potatoes (Mahmud et al., 2009; Eeswaran et al., 2016). At present, local potato production is insufficient to meet the demand. Therefore, importation is required to fulfil the demand in Sri Lanka (Abhayapala et al., 2014). According to the DCS (2017) annual importation of potatoes in Sri Lanka is about 148, 000 MT. Hence, there is a necessity for increasing local potato production. A study from Koch et al. (2020) discovered that negative effects of environmental (abiotic) factors can be minimized using balanced agronomic management strategies. Selecting the best cultivar, adequate nutrition management, continuous water supply, and plant protection are some important agronomic measures. Specially applying of sufficient amount of mineral nutrients can protect the potato plant against adverse growth conditions, which is crucial to achieve high yield and improve the quality parameters. Besides, crucial information for farming activities is available at various sources such as books, leaflets, newspapers, videos, radio, and TV programs etc. in different formats. Therefore, there are difficulties in accessing the complete guideline of contextspecific actionable information to make informed decisions for real-time problems (Glendenning et al., 2010; Ginige et al., 2016). Moreover, the inputs needed for potato cultivation is comparatively intensive to the cultivation of other field crops. Especially the seed potatoes account for more than $50 \%$ of the total cost due to the unavailability of quality seeds at a reasonable price. Lack of adoption of technology increases production costs and reduces returns (Fernando and Premasiri, 2006; Wickramasinghe and Jayasooriya, 2012).

Many developing countries are being used ICT based approaches like mobile platforms to make plans, manage agriculture, rural development, and agribusiness tasks (Henegedara, 2015). Chhachhar et al. (2014) stated that ICT plays a vital role in sharing knowledge and information for agriculture and supports farmers to make effective decisions. Further, Cieslik et al. (2018) found that increasing the availability of ICT promises management and monitoring the complex ecological problems and enhance knowledge sharing among relevant parties by generating timely context-specific information. Among different ICT tools, Muto and Yamano (2011) observed that the expansion of mobile phone coverage increased crop production and information flow among farmers. Crop production is location-specific; therefore, it is important to get information on agronomic practices, input availability, real-time market prices, and weather information. The Central Bank (2019) also reported that mobile phone usage has increased among the people in Sri Lanka in the recent past. Providing agricultural information by coupling the increased use of the Internet and other digital technologies and mobile phone usage brings attraction among farming communities worldwide. This is a feasible solution to disseminate up-to-date agricultural techniques correctly and quickly among farming communities than the traditional knowledge-sharing systems. Therefore, developing a real-time mobile-based information system to provide information and knowledge needed by farmers in a user-friendly manner is a suitable solution to overcome the major challenges and enhance long-term sustainability in the potato production of Sri Lanka.

Therefore, this research was conducted 1) to identify various challenges faced by the potato farmers in Sri Lanka; 2) to design the Packages of 
Practice (PoP) for different farming lifecycle stages of the potato production and 3) to provide contextspecific and actionable information through a mobile-based information system to overcome the challenges and achieve the sustainability in the potato production.

\section{METHODOLOGY}

The study was conducted in major potato growing areas in Sri Lanka. Potato is extensively grown in Nuwara Eliya district and it is also widely grown in Badulla district in paddy fields and high land in two major seasons, "Yala" and "Maha". The other two districts named Jaffna and Puttalam grow potatoes to a lesser extent (Horticultural Crop Research and Development Institute - HORDI, 2019). Nuwara Eliya district is situated in the central province of Sri Lanka. It has an area of $1,741 \mathrm{~km}^{2}$ and geographical coordinates are $7^{\circ} 00^{\prime}$ north and $80^{\circ}$ $45^{\prime}$ east. Badulla district is located in the Uva province of Sri Lanka and the entire land area is about $2,861 \mathrm{~km}^{2}$. The district lies between $6^{\circ} 59^{\prime}$ $05^{\prime \prime}$ north and $81^{\circ} 03^{\prime} 23^{\prime \prime}$ east. Besides, the Jaffna district is located under North province and it has an area of $1,025 \mathrm{~km}^{2}$. Geographical coordinates are $9^{\circ} 39^{\prime} 53^{\prime \prime}$ north and $80^{\circ} 1^{\prime} 0^{\prime \prime}$ east.

A purposive sampling technique was used to select 100 potato farmers as the target population from major potato growing areas in Sri Lanka to address the first objective. Based on the population density of potato farmers among the study areas 46 farmers were selected from Boralanda and Keppetipola areas (Badulla), 38 farmers from Seetha Eliya and Blackpool (Nuwara Eliya), and the remaining (16) was selected from Puthoor and Urumburai (Jaffna). The primary data were collected through face-to-face interviews using a pre-tested structured questionnaire. The key variables collected were age, education level, land extent, challenges faced by the farmers, production purpose, potato varieties use, input types, production cost, and irrigation methods. The secondary data were gathered from relevant institutions (Agriculture Research and Development Centre - Seetha Eliya, Department of Agriculture, HARTI, Department of Census and Statistics, Agrarian service centres), theses, books, and research articles, etc. The data were tabulated and analysed through Descriptive and Chi-Square statistical methods with the help of the statistical software SPSS (Version 25).

To fulfil the second and third objectives, Design Science Research (DSR) methodology was used as the research approach. It is a constructive research method and generates an innovative artifact as a research output. Thereby creating new knowledge and design artifacts were both useful and fundamental in understanding real-world problems (Hevner et al., 2004). Information Technology (IT) artifacts can be the constructs (symbols and vocabulary), models (abstractions and representations), methods (algorithms and practices), and instantiations (implemented and prototype systems) (March and Smith, 1995). The constructs provide language for communication and the definition of identified problems and solutions. Models help to understand and represent the problem and its solution to the realworld using constructs. Methods describe processes, which guides to solve the problem gradually (how to search the solution space). Instantiations show how can be constructs, models or methods implemented in a working system. This demonstrates the feasibility, doing a concrete assessment of an artifact's suitability to its target need (March and Smith, 1995).

Figure 1 indicates the three cycles of the DSR consists; Relevance, Design, and Rigor. The relevance cycle finds out the requirements from a contextual environment and takes into the research activities. As a result, artifacts are produced in the environment. The rigor cycle provides grounding knowledge to take part in the research activities and new knowledge is included as a result of these activities. Therefore, it bridges the design science activities with scientific theories, experience, and expertise in the research domain. Finally, artifact construction and evaluation under the research activities are carried out in the design cycle operation (Hevner, 2007).

Every crop has a farming life cycle during production. It was classified into five major stages referred to as variety selection, pre-planting, growing, harvesting, and post-harvesting. Hence, to provide contextual information to the farmers through a mobile-based application on a real-time basis, the conditions/ parameters/ factors/ constraints concerning each stage of the potato farming life cycle were identified using primary and secondary data sources. The model was developed using those factors that are called Packages of Practice (PoP). It is defined as guidelines (i.e. a set of rules) or design criteria for different activities in each stage of the farming life cycle which are developed based on the identified factors that affect the farmers' decision. Then the PoP model was verified through formal and informal discussions with domain experts (experienced farmers, agriculture instructors, and research officers). Based on the farmer context and feedbacks from domain experts (by several group 


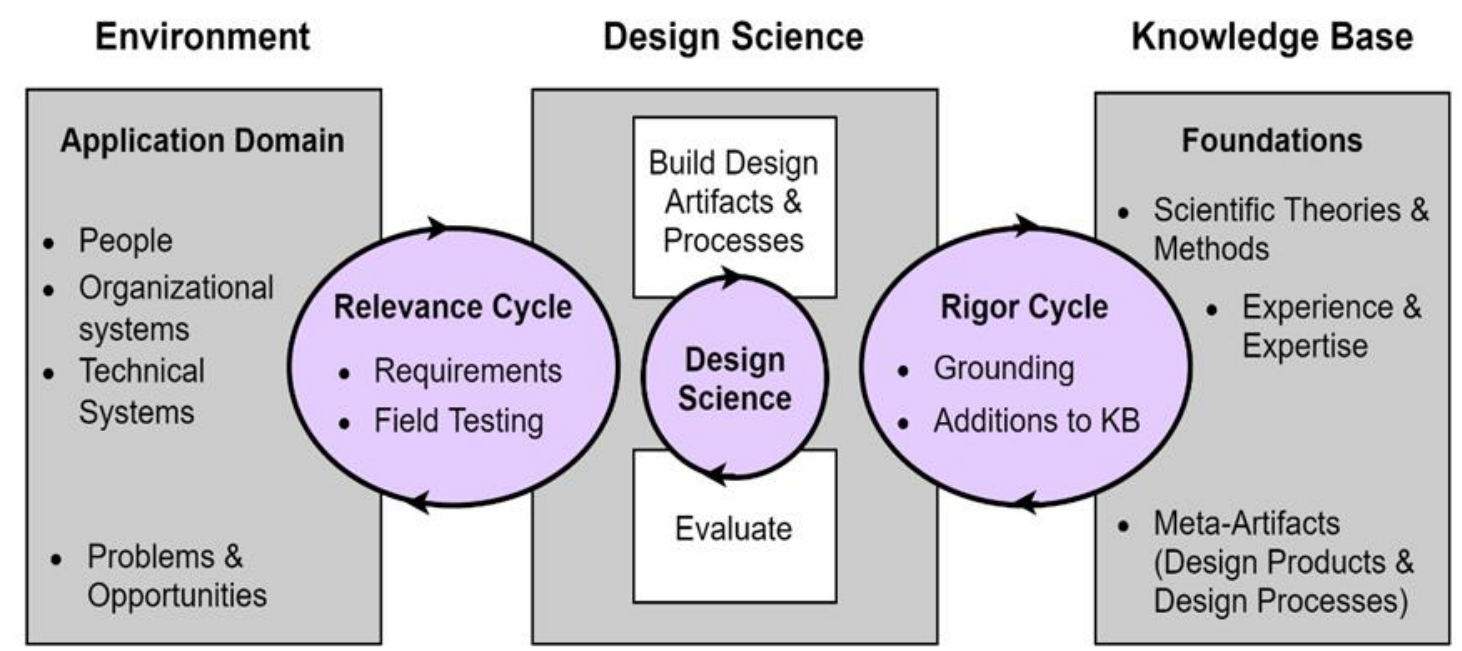

Figure 1: Design science research cycles (Hevner, 2007)

discussions), the PoP was refined and generalized. Finally, the existing ontological crop knowledge base discussed in (Walisadeera et al., 2015) was enhanced based on the proposed PoP that is now used in the "Govi-Nena" ("Farmers' Intelligence") mobile application (http://www.govinena.lk/).

\section{RESULTS AND DISCUSSION}

\section{Overview of the present status of major potato growing areas in Sri Lanka}

Among 100 potato farmers, the majority (55\%) were in the $46-65$ age group while $31 \%$ of them were in $26-45$, and $8 \%$ of them were less than 25 age groups. Limited numbers of farmers (6\%) were in higher than 66 age group indicating that the considerable involvement of young generation for in the potato cultivation. Further, the majority of farmers (47\%) have passed GCE 0/L while $27 \%$ of them have completed only up to grade 8 , and $19 \%$ of farmers have passed GCE A/L. Only 7\% have completed university education.

As shown in Figure 2 the majority of farmers from three major potato growing areas have a land area of less than 1.5 acres. This reflects that the majority of potato farmers are smallholders. Thus, they could not get a satisfactory profit from their harvest due to an increase in production cost. When comparing the production purpose of the potato, many farmers have cultivated potatoes for ware consumption than for seed potatoes (Figure 3). Because, majority of farmers preferred imported seeds, as they believe that imported seed potatoes have superior characteristics such as quality, yield per area, seed viability rate, seedling health, and tolerance against pest and disease attacks, etc. compared to the locally produced seeds. Further, the maintenance of proper environmental conditions is necessary for the successful production of seed potatoes. In Jaffna, not a single farmer practiced seed potato production due to improper climatic conditions for seed potato production. However, some farmers in Badulla and Nuwara Eliya are producing seed potatoes in both Yala and Maha seasons. The seed potato production was comparatively greater in Nuwara Eliya than that from the Badulla district. The majority of farmers in Badulla cultivate potato in the paddy fields during Yala after paddy cultivation and the paddy fields are not suitable for seed potato production. Despite this, Kuruppu et al. (2020) indicated that paddy cultivation provides good fallowing conditions for successful potato production. Further, a limited number of farmers had used seeds produced by themselves for the cultivation and some farmers bought seed from Potato Research Centers, Seetha Eliya and Kahagolle. 


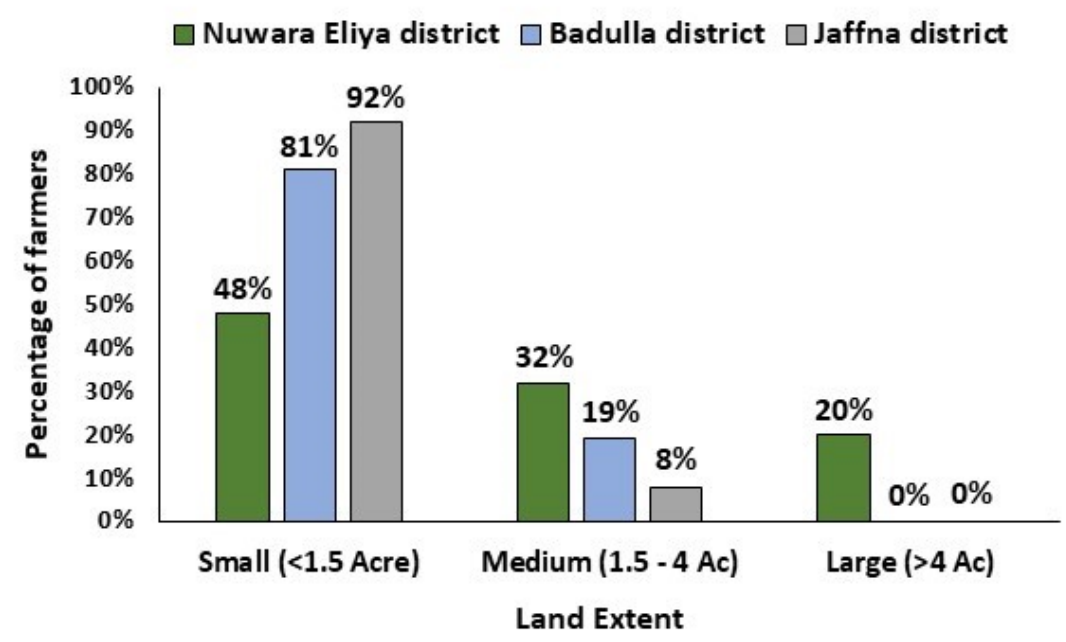

Figure 2: The land extent in the study areas

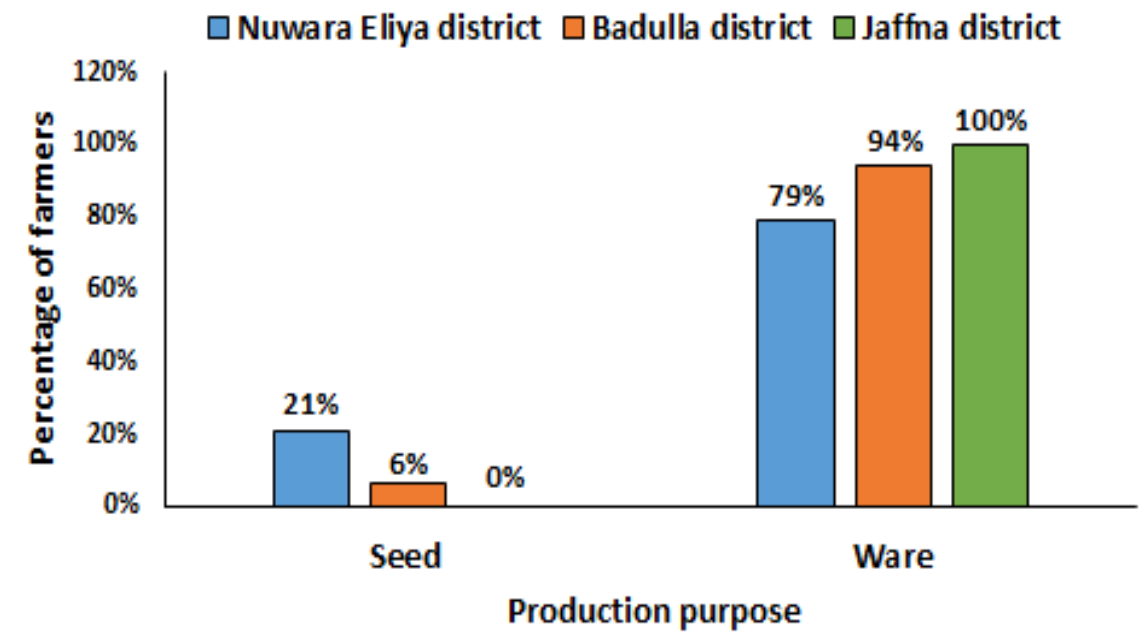

Figure 3: Production purpose of potato

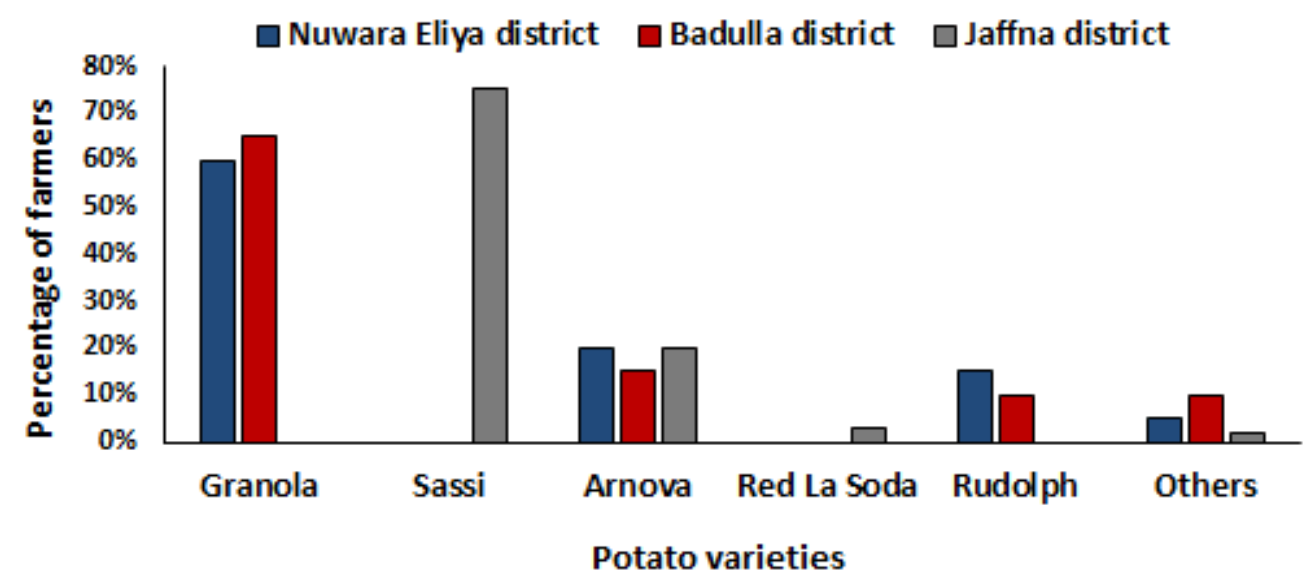

Figure 4: Potato varieties cultivated in Sri Lanka 
Figure 4 indicates that the majority of farmers in Jaffna cultivate a variety of "Sassy". But the most suitable and recommended variety for the Jaffna area is "Red La Soda". Based on the seed subsidy provided by the government, farmers change the variety occasionally. But in the upcountry of Sri Lanka (Badulla and Nuwara Eliya), "Granola" is the popular variety due to its resistance to external damages, potato blight (foliage and tuber) and virus diseases. Moreover, the skin thickness and shelf life of granola are also greater than other varieties, and a better fit for the climate conditions in the area. Therefore, $80-90 \%$ of local production comes from the Granola variety.

Furthermore, the study found that low farm gate prices, pest and disease attacks, and high cost of farm inputs were major challenges faced by the potato farmers in Sri Lanka as indicated in Figure 5. The majority of farmers said that improper agronomic practices, outdated and incomplete information about potato production, excess use of agrochemicals, sub-optimal quality, improper coordination among the farmers, lack of agrotechnology, and involvement of a large number of intermediaries in the potato value chain were main reasons for these challenges. Moreover, it was identified that the importation of the four-third of potatoes for the local requirement also indirectly affects the low farm gate price.

Figure 6 describes that the distribution of key challenges among farmers in the study areas. Low farmgate price was the main issue for potato farmers in Badulla and Jaffna while pest and disease attack was the major challenge for farmers in Nuwara Eliya. When considering the pest and diseases, the potato early blight, late blight and bacterial wilt were common diseases; mite, whitefly and potato tuber moth were the common pest attacks faced by the majority of farmers in surveyed areas. The high cost of farm inputs also considerably influenced the potato industry in Sri Lanka. Thus, seed potato accounts for about $63 \%$ of the total cost while $18 \%$ for water, $12 \%$ for labour and types of machinery and the remaining cost was $7 \%$ for fertilizer and agrochemicals. These values can be differed based on the farm location, availability of inputs, economic status of farmers, and preferences. The cost of water mainly due to the establishment of different types of irrigation systems in their field. This cost can be minimized if farmers use the rain-fed method. However, the use of an efficient irrigation method is important to obtain a higher yield. Among study areas, farmers have used furrow irrigation, hose method and sprinkler irrigation system for water application to their potato fields. In Badulla, 74\% of farmers used the hose method while $16 \%$ used drainage methods and $10 \%$ of farmers established sprinkler irrigation systems. Eighty-eight percent of Nuwara Eliya farmers used the hose method while others $(12 \%)$ used sprinklers. In Jaffna, the majority of farmers (96\%) used the hose method while $4 \%$ used sprinkler systems.

The Chi-Square test was used to analyse the significance of the association between potato growing districts and key challenges faced by the farmers. The result shows that the p-value (0.496) is higher than the significance level (0.05). Thus, do not reject the null hypothesis. No association was found between the variables. It is clearly explained that key challenges were not significantly distributed among study areas. Moreover, the same Chi-Square test was used to analyse the association between key challenges and age group and the education level of the farmers. The results indicate that p-values 0.755 and 0.387 accordingly. This reflects no association between these variables.

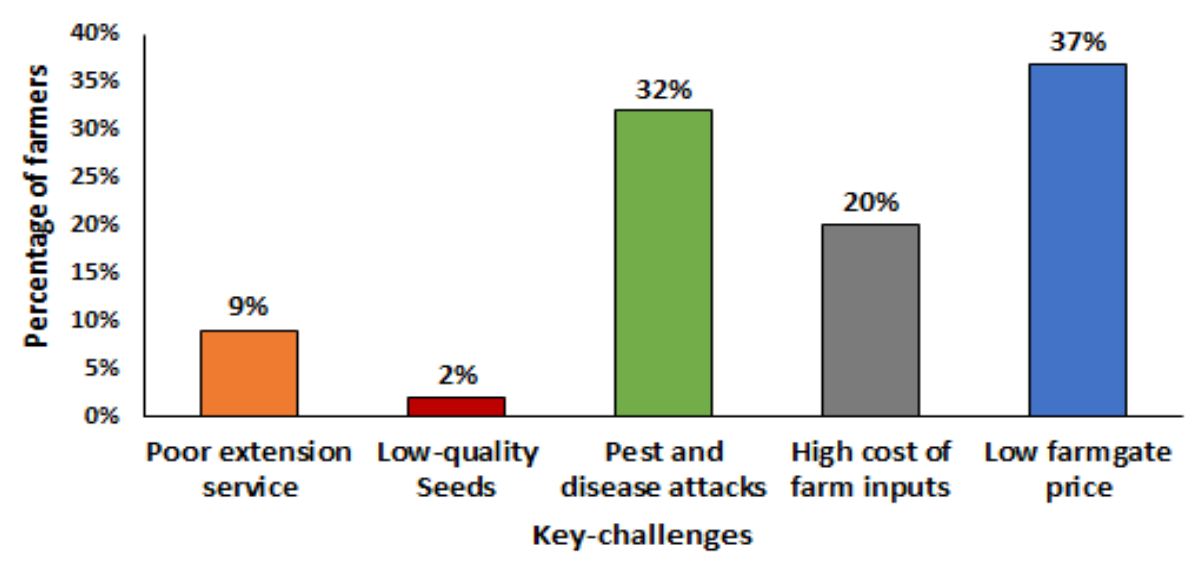

Figure 5: Key challenges faced by the potato farmers in Sri Lanka 


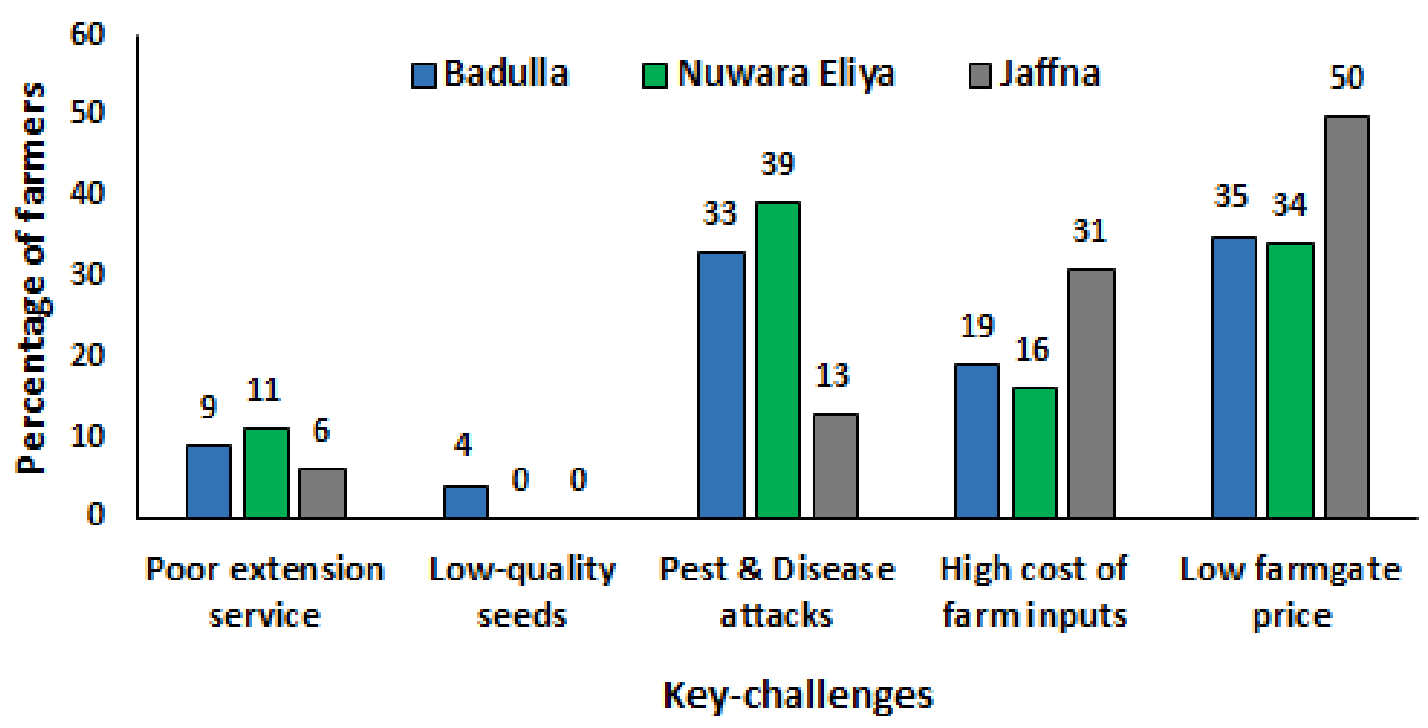

Figure 6: The distribution of key challenges among farmers in the study areas

\section{Design a model for the Packages of Practice (PoP) of potato production}

A technology-based solution can be suggested to address some of the issues observed in this study, which will be provided farmers with a platform to take the correct decisions at the right time for effective farming. At present, there were many agriculture-based mobile applications developed in Sri Lanka. But Gross Domestic Product (GDP) contribution from agriculture $(7.4 \%)$ is still being showcased in the diminishing value (DCS, 2019) because the available mobile applications are mainly focused on limited specific areas in crop production rather than farming life cycle as a whole process. Hence, a user-friendly mobile solution needs to be designed with all the features which are necessary for the farmers to access the required information at right time. By providing contextspecific information promptly through a mobile application could increase crop production and then it will increase the contribution of agriculture to GDP in Sri Lanka.

Figure 7 (see the Decision-support factors) shows various conditions/ parameters/ factors/ constraints concerning the stages in the potato farming life cycle identified using DSR methodology. The showcased factors are the main factors in the stages of the farming life cycle and these factors depended on some other factors called sub-factors to assist farmers in focusing on effective production. The first stage of the potato farming life cycle is variety selection and the mobile application in this stage provides information about various types of potatoes, suitable and unsuitable soils, level of tolerance for pests and diseases and physical damages, maturity level, tuber characteristics (shape, size, skin colour, flesh colour, and tuber quality), average yield, seed rate, and the season for cultivation for different potato varieties. The revised classification of agroecological regions (46) in Sri Lanka (Punyawardena et al., 2003; Chithranayana and Punyawardena, 2008) incorporated into the application (with details of recommended potato varieties) can correctly identify the agro-ecological region of the land which is going to be used for the cultivation. Thus, the mobile application suggests suitable varieties for the farm location automatically. Then, farmers can select one or more varieties in the list for the cultivation purpose based on their preference. Information about land preparation, seed sowing, fertilizer application (basal), pest and disease management (prevention), and weed management have been given in the second stage which is named as the pre-planting stage. Under the growing stage, all cultural practices like fertilizer application (1st and 2nd top dressings), pest and disease management (control), weed management, and specific operations (earthing up and dehaulming) are provided. The information of time of harvesting, frequency and methods of harvesting are provided in the harvesting stage. In the final stage (postharvesting) seed treatment and storage information are given.

Then, based on the identified factors and subfactors, a model was developed with complete information that is called PoP (see Potato PoP Workbook in figure 7). However, some activities in 

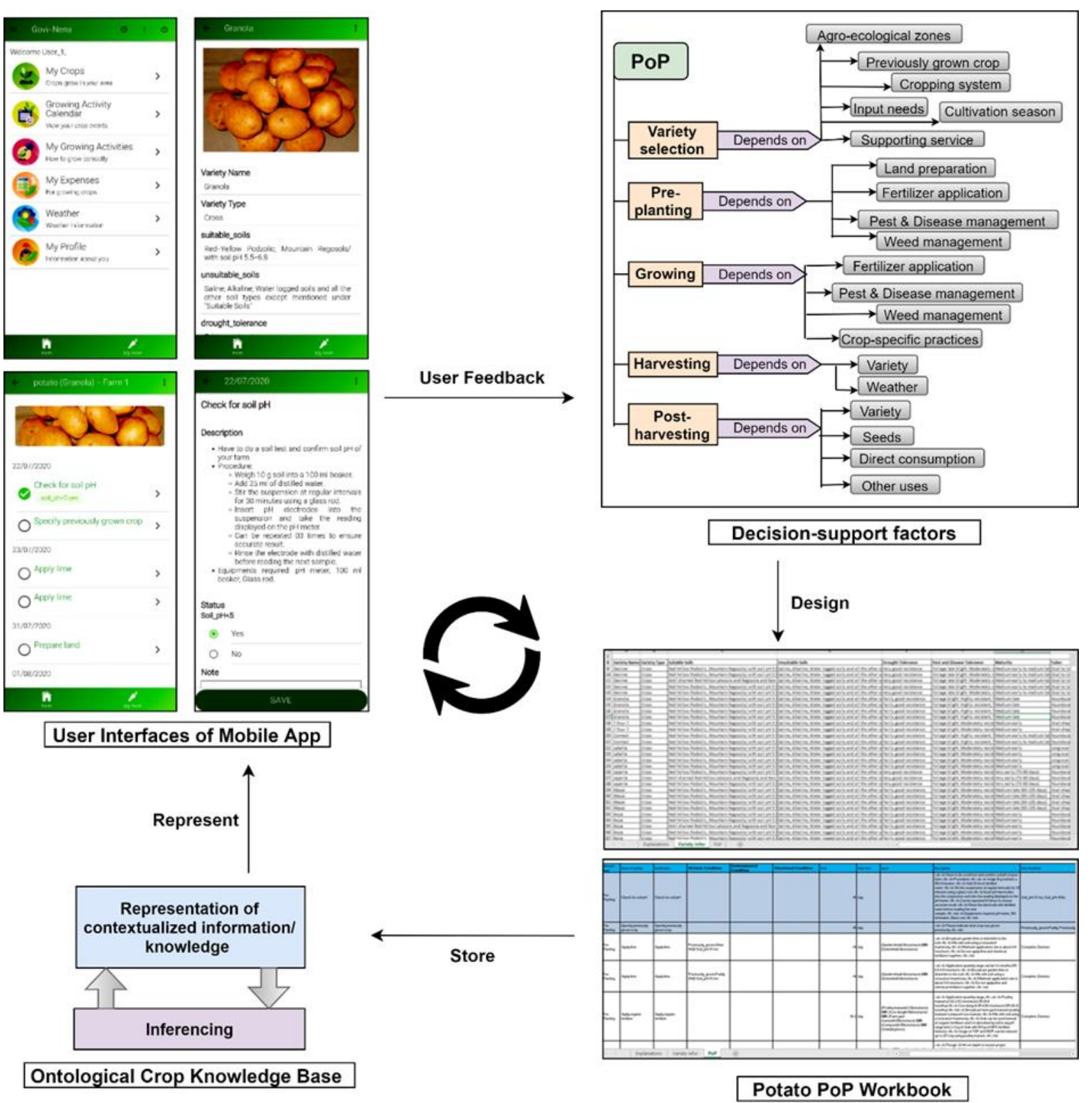

Figure 7: Information flow model for the development of potato PoP

the farming life cycle might happen depending on different conditions. To provide context-specific actionable information influencing conditions were subdivided into 3 groups. They are: 1) Historical conditions (previously grown crop and cultural practices sometimes affect the growth of the current crop. For instance, when growing potato if paddy was the previous season crop, the amount of lime that needs to be applied during land preparation is lesser than other crops). 2) Environmental conditions (irrigation methods available, inputs requirements and cultural practices differ with the environmental conditions. For instance, when applying fertilizers, the rate of application and type of fertilizers can be differed based on the farm location). 3) Situational conditions (unexpected conditions like extreme weather conditions change the activities to be performed. For instance, if there is a pest or disease attack in the growing field, suitable remedial actions need to be taken).

Thus, the PoP prepared consists of timely needed information which is necessary for farmers to make the right decisions at each stage of the potato farming life cycle in a sequential manner. Designed PoP was represented in the ontological crop knowledge base for inferencing (see Ontological 
crop knowledge base in figure 7) and finally crop information in farmer context was delivered through a real-time mobile-based information system (see User interfaces of mobile application in figure 7). However, PoP will be modified/ redesigned and proposed information flow will be continued based on the updated information and user satisfaction/ feedback. To address the language difficulty among farmers, PoP was prepared in three languages (Sinhala, Tamil and English) used in Sri Lanka. The mobile application ("Govi-Nena") discussed in this paper is currently available in three languages at both Google Play Store and Apple App Store in providing contextual information/knowledge to the farmers for successful farming (refer "Govi-Nena Farmer" app and http://www.govinena.lk/.

\section{CONCLUSION}

The study revealed that the majority of potato farmers in Sri Lanka are smallholders and cultivate few potato varieties mainly for ware consumption purposes. The key challenges faced by the farmers were observed as low farm gate price, pest and disease attacks, and high cost of farm inputs. The non-adoption of proper agronomic practices, unavailability of up-to-date complete information about potato production, overuse of agrochemicals, lack of and low quality of technology adoption, etc. were identified as the causes of key challenges. Therefore, contextspecific and actionable information is required for the farmers to get correct decisions for effective

\section{REFERENCES}

Abhayapala, K.M.R.D., Costa, W.A.J.M.D., Fonseka, R.M., Prasannath, K., Costa, D.M.D., Suriyagoda, L.D.B., Abeythilakeratne, P.D. and Nugaliyadde, M.M. (2014). Response of potato (Solanum tuberosum L.) to increasing growing season temperature under different soil management and crop protection regimes in the upcountry of Sri Lanka. Tropical Agricultural Research, 25(4), 555. doi: 10.4038/tar.v25i4.8061.

Bandara, D.G.V.L. and Thiruchelvam, S. (2008). Factors affecting the choice of soil conservation practices adopted by potato farmers in Nuwara Eliya district, Sri Lanka. Tropical Agricultural Research and Extension.

Central Bank (2019), Economic and Social Infrastructure, Annual Report 2019, Central Bank of Sri Lanka. farming. Hence, factors and sub-factors which affect the decisions throughout the potato farming life cycle were identified. The proposed PoP model was designed based on those factors. Moreover, a set of different categories of conditions were applied to the PoP that supports some activities during production. The potato $\mathrm{PoP}$ will be modified based on the updated information/knowledge and user feedback. Finally, the PoP with 3 languages was implemented and delivered through the "GoviNena" mobile-based information system. The first version of this application is now available in both Google Play Store and Apple App Store. This will be promised a better solution to minimize key issues and achieve the sustainability of potato production in Sri Lanka.

\section{ACKNOWLEDGEMENTS}

This research was supported by the Accelerating Higher Education Expansion and Development (AHEAD) Operation of the Ministry of Higher Education funded by the World Bank. The authors wish to express their profound gratitude to the officials from the Uva Provincial Department of Agriculture, Agriculture Research and Development Centre- Seetha Eliya. A special thanks goes to the assistance given by the Agriculture Instructors as well as Farmers in Badulla, Nuwara Eliya, and Jaffna districts.

Chhachhar, A.R., Qureshi, B., Khushk, G.M. and Ahmed, S. (2014). Impact of information and communication technologies in agriculture development. Journal of Basic and Applied Scientific Research, 4(1), 281-288.

Chithranayana, R.D. and Punyawardena, B.V.R. (2008). Drought prone agro-ecological regions in Sri Lanka. Journal of National Science Foundation, 36(2), 117-123.

Cieslik, K.J., Leeuwis, C., Dewulf, A.R.P.J., Lie, R., Werners, S.E., Wessel, M.V., Feindt, P. and Struik, P.C. (2018). Addressing socio-ecological development challenges in the digital age: Exploring the potential of Environmental Virtual Observatories for Connective Action (EVOCA). NJAS - Wageningen Journal of Life Sciences, Elsevier, 86-87, 2-11. doi: 10.1016/j.njas.2018.07.006.

Department of Census and Statistics (DCS), Sri 
Lanka, 2017.

Department of Census and Statistics (DCS), Sri Lanka, 2019.

Eeswaran, R., Costa, W.A.J.M.D., Costa, D.M.D., Dandeniya, W.S., Sivakumar, S. and Suriyagoda, L.D.B. (2016). Evaluation of a climate changeadaptive, eco-friendly agronomic package for potato (Solanum tuberosum L.) cultivation in the farmer fields of the Jaffna district of Sri Lanka. Tropical Agricultural Research, 27(2), 190. doi: 10.4038/tar.v27i2.8167.

Evans, L.T. and Fischer, R.A. (1999). Yield potential: its definition, measurement, and significance. Crop Science, 39, 1544-1551. doi: 10.2135/cropsci1999.3961544x.

FAO (2009) Potato and Food Price Inflation. International Year of the Potato 2008. Food and Agriculture Organization of the United Nations, Rome.

Fernando, P. and Premasiri, H.M.R. (2006). Evaluation of productivity of potatoes in Nuwara Eliya and Badulla districts with the aid of GIS techniques. Vidyodaya Journal of Science, $13,49-64$.

Ghebreslassie, B.M., Githiri, S.M., Mehari, T. and Kasili, R.W. (2014). Potato seed supply, marketing and production constraints in Eritrea. American Journal of Plant Sciences, 5, 3684-3693.

Ginige, A., Walisadeera, A.I., Ginige, T., De Silva, L., Di Giovanni, P., Mathai, M., Goonetillake, J., Wikramanayake, G., Vitiello, G., Sebillo, M., Tortora, G., Richards, D. and Jain, R. (2016). Digital knowledge ecosystem for achieving sustainable agriculture production: A case study from Sri Lanka. Proceedings of 3rd IEEE International Conference on Data Science and Advanced Analytics, DSAA 2016, 602-611. doi: 10.1109/DSAA.2016.82.

Glendenning, C.J., Babu, S. and Asenso-Okyere, K. (2010). Review of agricultural extension in India. are farmers' information needs being met?. International Food Policy Research Institute. Eastern and Southern Africa regional office.

Henegedara., G.M. (2015). Information and Communication Technology (ICT) and Rural and Agricultural Development in Sri Lanka. First International Conference on Theory and Practice (ICTP).
Hevner, A.R., March, S.T., Park, J. and Ram, S. (2004). Design science in information systems research. Management Information Systems Quarterly Journal, 28(1), 75-105.

Hevner, A.R. (2007). A three cycle view of design science research. Scandinavian Journal of Information Systems, 19(2), 1-6.

Horticultural Crop Research and Development Institute (HORDI), Department of Agriculture, Peradeniya, Sri Lanka (2019). Potato. [on line]. [Accessed on 25.07.2020]. Available at: https://doa.gov.lk/HORDI/index.php/en/crop -en/51-potato-e.

Koch, M., Naumann, M., Pawelzik, E., Gransee, A. and Thiel, H. (2020). The importance of nutrient management for potato production part I: plant nutrition and yield. Potato Research. Springer. 63(1), 97-119. doi: 10.1007/s11540-01909431-2.

Kuruppu, V., Amarakoon, D. and Fernando, S.P. (2020). Strengthening quality seed potato production in Sri Lanka through viable PublicPrivate Partnerships (PPP). Applied Economics and Business, 4(1), 33-44.

Mahmud, A.A., Akhter, S., Hossain, M.J., Bhuiyan, M.K.R. and Hoque. M.A. (2009). Effect of dehaulming on yield of seed potatoes. Bangladesh Journal of Agricultural Research, 34(3), 443-448. doi: 10.3329/bjar.v34i3.3970.

March, S.T. and Smith, G.F. (1995). Design and natural science research on information technology. Elsevier. 15(4), 251-266. doi: 10.1016/0167-9236(94)00041-2.

Michel, A., Sinton, S.M., Falloon, R.E., Shah, F.A., Dellow, S.J. and Pethybridge, S.J. (2015). Biotic and abiotic factors affecting potato yields in Canterbury, New Zealand. Proceedings of the 17th ASA conference, Hobart, Australia, 211214.

Muto, M. and Yamano, T. (2011). Mobile phone coverage and market participation: The case of banana marketing in Uganda. Springer, 99-113. doi: 10.1007/978-94-007-1201-0.

Punyawardena B.V.R., Bandara T.M.J., Munasinghe M.A.K., Banda N.J. and Pushpakumara S.M.V. (2003). Agro-ecological regions of Sri Lanka. Natural Resources Management Center, Department of Agriculture, Peradeniya.

Qadri, R.W.K., Khan, I., Jahangir, M.M., Ashraf, U., 
Samin, G., Anwer, A., Adnan, M. and Bashir, M. (2015). Phosphorous and foliar applied nitrogen improved productivity and quality of potato. American Journal of Plant Sciences, 6(1), 144-149. doi: 10.4236/ajps.2015.61016.

Rykaczewska, K. (2013). The impact of high temperature during growing season on potato cultivars with different responses to environmental stresses. American Journal of Plant Sciences, 04(12), 2386-2393. doi: 10.4236/ajps.2013.412295.

Walisadeera, A.I., Ginige, A. and Wikramanayake, G.N. (2015). User-centered ontology for Sri Lankan farmers. Ecological Informatics, 26(2), 140-150. doi: 10.1016/j.ecoinf.2014.07.008.

Wickramasinghe, W. and Jayasooriya, C. (2012). Multiple effects and impact of small farmer (FFS based) seed potato production in Badulla district, Colombo. HARTI. 